\title{
Implementing tablets to teach Reading in Grade 5
}

\begin{tabular}{|c|c|}
\hline \multicolumn{2}{|c|}{ 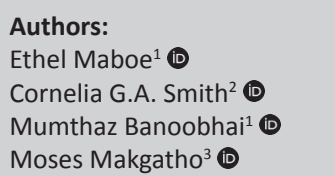 } \\
\hline \multicolumn{2}{|c|}{$\begin{array}{l}\text { Affiliations: } \\
\text { }{ }^{2} \text { Department of and } \\
\text { Educational Studies, Faculty } \\
\text { of Humanities, Tshwane } \\
\text { University of Technology, } \\
\text { South Africa }\end{array}$} \\
\hline \multicolumn{2}{|c|}{$\begin{array}{l}{ }^{2} \text { Department of Applied } \\
\text { Languages, Faculty of } \\
\text { Humanities, Tshwane } \\
\text { University of Technology, } \\
\text { South Africa }\end{array}$} \\
\hline \multicolumn{2}{|c|}{$\begin{array}{l}{ }^{3} \text { Department of Technology } \\
\text { and Vocational Education, } \\
\text { Faculty of Humanities, } \\
\text { Tshwane University of } \\
\text { Technology, South Africa }\end{array}$} \\
\hline \multicolumn{2}{|c|}{$\begin{array}{l}\text { Corresponding author: } \\
\text { Cornelia Smith, } \\
\text { smithcga@tut.ac.za }\end{array}$} \\
\hline \multicolumn{2}{|c|}{$\begin{array}{l}\text { Dates: } \\
\text { Received: } 06 \text { Feb. } 2018 \\
\text { Accepted: } 17 \text { May } 2018 \\
\text { Published: } 27 \text { July } 2018\end{array}$} \\
\hline \multicolumn{2}{|c|}{$\begin{array}{l}\text { How to cite this article: } \\
\text { Maboe, E., Smith, C.G.A., } \\
\text { Banoobhai, M. \& Makgatho, } \\
\text { M., 2018, 'Implementing } \\
\text { tablets to teach Reading in } \\
\text { Grade 5', Reading \& Writing } \\
\text { 9(1), a197. https://doi.org/ } \\
\text { 10.4102/rw.v9i1.197 }\end{array}$} \\
\hline \multicolumn{2}{|c|}{$\begin{array}{l}\text { Copyright: } \\
\text { (c) 2018. The Authors. } \\
\text { Licensee: AOSIS. This work } \\
\text { is licensed under the } \\
\text { Creative Commons } \\
\text { Attribution License. }\end{array}$} \\
\hline \multicolumn{2}{|c|}{ Read online: } \\
\hline 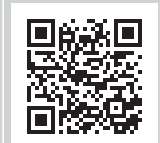 & $\begin{array}{l}\text { Scan this QR } \\
\text { code with your } \\
\text { smart phone or } \\
\text { mobile device } \\
\text { to read online. }\end{array}$ \\
\hline
\end{tabular}

Literacy is regarded as a fundamental skill for people to communicate successfully in all areas of life. In the light of the poor performance of learners, an investigation concerning reading is imperative to enhance literacy in South Africa. This study explores the use of tablets to enhance English reading among learners in Grade 5 from selected primary schools in Atteridgeville. The sample consisted of 12 learners, six teachers and six parents. Tablets form part of connectivity because modern technology is used to draw the learners into listening and reading English. Technological Pedagogical Content Knowledge focuses on the use of modern technology to enhance teaching and learning in education. The study followed a qualitative approach involving a case study. Focus group interviews and observations were used as research instruments. The findings of the investigation reveal that learners using tablets have an advantage, because modern digital natives enjoy the use of technology to communicate and learn, which enhances their reading and learning. Tablets provide learners with the opportunity to experience technology physically and independently. Audiobooks used on tablets were a great help to facilitate reading development in English, especially with regard to vocabulary branching and correct pronunciation. Funds are still a problem because the use of technology does not happen in all educational environments.

\section{Introduction}

Teaching the millennials demands more than the usual teacher-orientated approach of enforcing silence when learning in the classroom. It requires innovation and adaptation with regard to the way teachers approach the learners who are far more accustomed to using technology than a few years ago. Technology has changed the insistence on learner-centred approaches as successful modern learning has become linked with technology-driven lessons that naturally involve learner-centredness without having to focus pertinently on being learner-focused. The integration of digital technologies, more specifically tablets, into learning and the reading experiences has become a priority for many teachers who have to keep abreast with modern inventions and how these influence the learners. Available apps grow exponentially on a daily basis. Literacy is also evolving and embraces the skills needed to function in a technological society. Literacy has also become an intricately interwoven part of our daily comprehension and the understanding of the world around us (Sara 2009:3).

Reading is defined as the cognitive process to interpret symbols and make meaning of a text. Reading can, therefore, be interpreted as making meaning from print. It involves:

- identifying the words in print which is called recognition

- constructing meaning and understanding from the print which is called comprehension

- coordinating and identifying words so that reading becomes automatic and accurate - an achievement identified as fluency (Leipzig 2001:1).

\section{Problem statement}

Because of technological inventions, teachers need to adapt the way they teach learners and learners need to be taught how to make use of technology to further their learning and education. A question that arises is the following: how can technology be fruitfully used in the modern classroom to improve reading? Poor reading results in schools have raised the concern of finding ways to improve reading performance (Gauteng Primary Literacy Strategy 2010:6). Readers are technologically orientated, yet technology is not used to its full potential (Royer 2002:234). Learning with technology is teacher-centred rather than learner-centred. If schools want teachers to use technology to enhance learners' learning, then it is important to address these issues. New ideas come and go and are rarely sustainable (Zarfass 2001:104). To avoid 'initiative fatigue', schools must focus not only on introducing new technology, but also on implementing and promoting the use thereof. 
Whilst every school is different, with different needs and resources, there are several factors that facilitate technology implementation and can help address the challenges mentioned above, making the school's efforts to develop reading more successful (Glazer, Hannfin \& Song 2005:57). Factors that facilitate implementation will play a role in every stage of the intervention, from the initial planning and exploration phase to help to sustain the intervention once fully implemented. Learning can be enhanced through e-learning and mediation tools such as tablets are needed to distribute the content to be covered in the learning situation (Aparicio, Bacao \& Oliveira 2016:29).

\section{Literature review}

\section{Theoretical background: Technological pedagogical content knowledge}

A prominent theory of relevance to this study is technological pedagogical content knowledge (TPACK). TPACK focuses on the nature of knowledge needed by teachers to integrate technology into the learning experience. Shulmans (1986:8) identifies TPACK as an effective theory to apply when integrating pedagogy and the researchers view it as relevant, because it focuses attention on the way the content is taught highlighting educational and academic content, bearing in mind the importance of the teachers' ability to use the technology effectively. The acronym TPACK is explained as:

- $\mathrm{T}$ : Technological knowledge - this knowledge involves the overall knowledge to implement different technologies effectively.

- P: Pedagogical knowledge - this knowledge comprises teachers' deep knowledge about the processes or methods of teaching and learning including assessment.

- A: Academic knowledge - this knowledge refers to the teachers' academic knowledge of the subject and how it can be communicated using technology.

- C: Content knowledge - this aspect comprises teachers' knowledge about the subject matter to be learnt or taught as content which is part of the prescribed syllabus.

- K: Knowledge - this is the basis of the TPACK approach as it forms an integral part of all the different fields of the TPACK theory (Koehler \& Mishra 2009:60-70).

It is best illustrated in Figure 1.

Technological pedagogical content knowledge serves as the foundation of efficient teaching with technology, requiring and understanding the unique concepts when incorporating technologies. Pedagogical techniques make room for using technologies such as tablets to teach the prescribed content. Concepts not often encountered can pose challenges in teaching and learning. Using technology can help to overcome some of the problems that teachers and learners face with reading, prior knowledge and theories of epistemology. Knowledge of incorporating technologies in lessons to stimulate prior knowledge can aid in developing new epistemologies and reinforcing old ones (Koehler \& Mishra 2009:67).

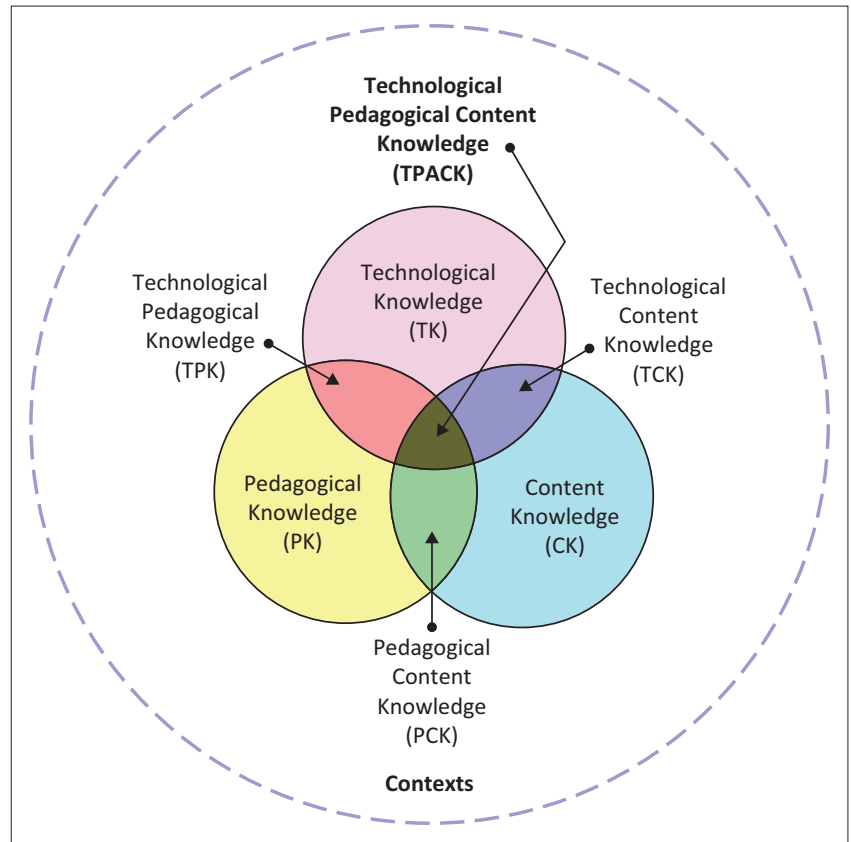

Source: Adapted from Koehler, M.J. \& Mishra, P., 2009, 'What is technological pedagogical content knowledge?', Contemporary Issues in Technology and Teacher Education (CITE Journal) 9(1), 60-70

FIGURE 1: Technological pedagogical content knowledge.

Tablets are used to implement audiobooks that offer a way to recapture enthusiasm for reading. The learners listen to the story recorded at a slower than usual pace (the recorded book method) which reduces much of the stress involved in reading. In order to become a proficient reader, a learner needs a combination of listening to comprehension and decoding skills by making use of technology to connect with the text. Repeated listening exposes learners to correct reading methods and pronunciation and stimulates interest. As the learners become independent readers, they need more options of interesting material and stimulating programmes which they may read alone or with peers. The power of audiobooks (via the use of tablets) to transform struggling readers can be attributed to a simple formula which presents material that is interesting because it is close to the learners' lived experiences (Carbo 1996:26).

\section{Tablets}

Apple introduced the iPad, a revolutionary tablet that came with an easy-to-use operating system, in 2010. Pongue (2010:4) observes that this tablet, as big as an old-fashioned paperback, has a high-revolution touchscreen function that is sharp enough to make reading books a pleasure. Technological inventions and developments are changing the way learners learn in schools. According to Eberwein (2013:1), the curriculum is fluid and dynamic to adapt to change and to implement new inventions. Using tablets to teach reading can customise the learning experience and promote learners' reading skills (Larson 2015:169). Tablets offer the option of audiobooks. Tablets are capable of holding the digital equivalent of hundreds of printed texts without the added bulk or measurable mass. This initiative hopes to ensure that all learners in Gauteng achieve the required outcomes and leave 
the educational institution with such knowledge, skills and qualifications that will give them the best chance of success in their adult life. Engelbrecht, Nel and Hugo (2013:221) advocate a modern approach to learning that promotes the use of technology. When these resources are available, technology can enhance learning. Robles de Melendéz and Beck (2007:430) propose the incorporation of technology in classrooms. They are also of the opinion that technological equipment can make a huge difference in communicating with the modern learners and parents at home, especially when a variety of cultures are involved.

In addition to the more traditional forms of literacy of using paper, pencil and print texts, modern students interact with new digital literacies, embracing tablets. Tablets help learners learn a wide range of materials faster. Reading aloud has long been acknowledged as a crucial component of effective reading programmes and, by some, it is considered to be the single most important activity for building knowledge which is required for reading success. Teachers believe that the use of tablets enriches classroom education and motivates learners to learn. The tablets can hold hundreds of textbooks on one device, plus homework, quizzes and other files, eliminating the need of physical storage of books and classroom materials. E-textbooks on tablets cost less than printed textbooks. It can also save the school money because the price of tablets continues to drop, making them increasingly affordable (Larson 2015:169).

Tablets contain many technological features that cannot be found in print textbooks, because they give users the ability to highlight and edit texts and write notes without ruining a textbook for the next user. Tablets allow learners to produce original work that will be a game changer. Printed textbooks are very heavy and can cause injuries to learners. Paediatricians and chiropractors recommend that learners carry less than $15 \%$ of their body weight in a backpack. According to the US Consumer Product Safety Commission, during 2011-2012, more than 13700 children aged 5-18 were treated for backpack-related injuries (Larson 2015:169).

Klein and Myers (1999:68) maintain that educational technology, in general, and tablets, specifically, hold the possibility of making the school a more efficient, friendly and personalised place for children. If you have a tabletbased approach, you can become informed faster and more effectively (Klein \& Myers 1999:68). Using technology in the classroom does not drive teaching, but rather creates a learning environment that offers more exciting learner-centred learning opportunities. Schools frequently ignore the broad capacities computers have for instructional support, isolating them from the learning process rather than integrating them into learning areas of the curriculum. Implementing the TPACK principles, focusing on how to use technology (tablets) and how to take into consideration the content and the pedagogical approaches to teaching effectively, teachers can incorporate technology to equip learners to prepare the lesson that they will teach in their classrooms. Teachers are beginning to use technology as a tool to promote learners' ability to reason and solve authentic problems. The use of existing technology, such as tablets to aid in transforming classrooms into dynamic centres, aims at achieving purposeful and experiential learning facilities, raising an awareness to authentic action (Moersch 1999:53).

When teachers thoroughly integrate technology into the classroom, a constructivist learning environment to promote pedagogy and cognitive knowledge can evolve. The learning environment is a place in which learners work together and support each other as they use a variety of information resources in their guided pursuit of learning goals and problemsolving activities. A constructivist learning environment frequently encompasses many different applications of media and technology (Middleton \& Murray 1999:110). In spite of the few apparent commitments to technology by some schools, it appears that many teachers use computers or tablets to support their current traditional teaching practices, rather than as a tool to promote more innovative, constructivist practices (Cuban 2001:20). Learners now embrace and use computers in more sophisticated ways than teachers and their parents (Fuller 2000:511).

\section{Listening practices}

Tablets are considered a valuable learning tool because of their format. Unlike traditional books or a video programme, one can learn from audiobooks on tablets whilst doing other tasks. Such tasks include doing exercises and travelling with public or private transport. Using tablets can help learners to relax and is a useful way to multitask and sustain interest. Common practices to enrich literature lessons in the classroom engaging audio lessons using tablets include:

- Replaying: depending on one's degree of attention and interest, it is often necessary to listen to segments of an audiobook more than once to allow the material to be understood and retained satisfactorily. Replaying may be performed immediately or after an extended period of time.

- Listening: people may listen to an audiobook (usually an unabridged one) using a tablet while following along in an actual book. This will help learners to learn words that they may not learn correctly if they were only to read the book. This can also be a very effective way to learn a new language.

- Multitasking: many audiobook listeners choose the format because it allows multitasking during otherwise mundane or routine tasks such as exercising, doing house chores or playing.

- Entertainment: audiobooks (using technology such as tablets) have become a popular form of travel entertainment for families or communities (Larson 2015:171).

When teaching learners to read English books using tablets, it is important to focus on assisting them to understand and become aware of the smallest sounds (phonemes). Speech sounds influence meaning and interpretation. The learner should be guided to segment words and blend phonemes into sounds. The most useful way is to teach the short and long vowels (over 300) and the different sounds of the ' $c$ ' and ' $g$ '. 
Direct instruction of whole words is also crucial for phonic analysis. The words ' $m-a-t$ ' and 'b-ea- $t$ ' consist of three phonemes and they are then sequenced and blended to produce spoken words. The teacher starts building onto the knowledge of sounds of the alphabet by teaching whole syllables and then proceeds to single sounds. Through phonemic awareness, the learner comprehends the alphabetic principle. Blending is crucial to decode new words and segmenting is necessary to learn how to spell (Choate 2004:66).

Phonics need to be taught in order to equip the learner to read. Phonics deals with the automaticity of sound-letter links. The learner should be able to recognise symbol sound correspondences and identify sounds. They should be able to identify them even if they sound similar but use different symbols. The learners need to say the word and understand the meaning of what is said. The 26 letters constitute the 44 phonemes in the English language. When writing English words, the alphabet letters are used in different combinations. It is crucial to note that different groups of letters can represent the same sound, for example, 'tried' and 'light' use the ' $\mathrm{ie}$ ' and ' $\mathrm{I}$ ' letters to communicate the same sound. Word recognition deals with the ability to listen to the sounds or to read the word in the text and recognise its meaning. It requires visual and auditory discrimination, memory and phonemic awareness (Nel \& Nel 2012:92-93). When using tablets to teach reading, it stands to reason that letter and sound recognition will play a role in learning to read.

\section{Applying the technological pedagogical content knowledge framework to pedagogy}

The understanding of the complex relationships among content, pedagogy and technology is a crucial, focal area. The standard approach suggests that teachers simply need to be trained to use technology. By demonstration of their proficiency with current software, teachers will be able to successfully incorporate technology into their classrooms. Shulman (1996:12) describes this emphasis as a form of applied technocratic rationality, a view that technology is self-contained and has an independent integrity and that to unlock its potential and power requires merely learning certain basic skills. This aforementioned statement implies that knowing technology automatically leads to quality teaching when using tablets in the classroom to teach reading skills. Koehler and Mishra (2005:98) assert that traditional methods of technology training for teachers, mainly workshops and courses, are ill-suited to produce the deep understanding that can assist teachers in becoming intelligent users of technology to teach reading in the classroom. It is necessary to do in-depth research on the specific needs of teachers in schools to understand their unique needs. There is a need for a learning environment to facilitate the development of a culture in which participants learn and grow. This community of learners must be diverse and should utilise an array of knowledge.
The online learning environment provides the framework for creating such mediation, as well as the ability to bring together a limitless perspective on any subject imaginable. E-learning is a synchronous online tool and is a mediator. The social area is achieved through the different types of communication, collaboration, cooperation and interaction that happen among the moderator and the learners online (Nehme 2000:247).

The International Society for Technology in Education (ISTE) (2009) identifies conditions described as necessary to effectively leverage technology (including the use of tablets) for learning. They are:

- A shared vision: proactive leadership creating a shared vision for educational technology among all educational stakeholders embracing teachers and support staff, learners, parents and the community must be facilitated.

- Empowered leaders: stakeholders at every level must be empowered to be leaders in effecting change, Implementation Planning.

- Consistent and adequate funding: ongoing funding to support technology infrastructure, personnel, digital resources and staff development must receive attention as well as equitable access.

- Skilled personnel: the Department of Education should focus on equipping teachers, support staff and other leaders skilled in the selection and effective use of appropriate e-learning and information and communication technologies (ICT) resources, implementing an ongoing framework.

- Learning: technology-related professional learning plans and opportunities must be created to dedicate time to practise and share ideas.

- Technical support: consistent and reliable assistance must be provided to assist with maintenance and renewing and use of the digital resources Curriculum Framework.

- Learner-centred learning: planning, teaching and assessment must centre on the needs and abilities of learners, assessment and evaluation.

- Engaged communities: partnerships and collaboration within communities must support and fund the use of digital learning resources.

- Support external context: policies and initiatives at the national, regional and local levels should be proposed to support schools and teachers.

In order to achieve sustainable and successful outcomes, a shared vision has to be a belief that technology is beneficial, as defined by different communities of users or practice and education models, and to be embraced with an open mind by all involved. Teachers should be guided to develop their capability to engage actively and collaboratively with learners. Effective integration and essential conditions should positively impact learning and it should be galvanised to support learners fully (Eickelmann 2011:75). The current research undertaken, focused on the practical implementation of tablets to teach reading and focused on ways to improve teaching using tablets. 


\section{Methodology Design}

Thyer (1993:94) defines research design as a detailed plan or a blueprint of how the study should be conducted. In the process, the researcher needs to select the sample of schools at which they will conduct the study, collect the data for testing the hypothesis, and analyse the results generated by interviews and open-ended questions. The design of this study is descriptive. Creswell (2009:5) identifies qualitative research as a specific, descriptive design. This study also involved a case study design. The term 'case study' is linked with a small number of units that are studied in detail (Welman, Kruger \& Mitchell 2005:193).

\section{A qualitative approach}

The study followed the qualitative research approach to explore personal experiences and responses of teachers, parents and learners to describe the methodologies of teaching reading, using audiobooks in the Intermediate Phase with specific reference to Grade 5. McMillan and Schumacher (2010:322) identify the following specific criteria as part of a qualitative research approach. Qualitative research happens in a natural setting and meaning is created by attempting to understand the respondents' behaviour in a specific context bearing in mind gender, racial, class and social and technological factors. Information in qualitative research is extracted directly from the source and the researchers should be close to the participants in that they understand the environment and needs of the participants. Descriptions are captured as part of the narrative to improve the interpretation of the data. Bless, Higson-Smith and Sithole (2013:16) emphasise that the researcher in qualitative research focuses on what the respondents feel and think about a particular phenomenon. Reality is interpreted from the respondents' frame of reference.

\section{Population and sampling}

According to Bless et al. (2013:162), the people about whom the researcher wants to determine some characteristics are called the population. Thus, in this instance, the population consists of the selected and sizeable number of possible candidates who participated in the study. The participants were six English teachers (English referring to the subject taught), 12 Grade 5 learners and six parents. The study was conducted in the Grade 5 English class at two selected primary schools in Atteridgeville and even though it was the English home language class, the focus was on English second language (ESL) as the African students attending the school have different mother tongues.

Qualitative research aims at studying people in their natural context and is inductive and holistic, and does not aim at generalising. It aspires to identify new knowledge that is transferrable to other units of the population (Bless et al.
2013:162). As the selected process is qualitative, purposeful sampling was used. Bless et al. (2013:172) contend that purposeful sampling is based on the judgement of the researcher. Participants were purposefully selected, bearing in mind that they should all be second language speakers of English and that both genders were involved by including an equal number of male and female participants. Results were shared and the two schools were able to benefit from the results. Purposeful sampling is based entirely on the view of the investigator, because the sample consists of the elements that mirror most characteristics of the selected population.

\section{Data collection}

The study involved a case study. In order to have a welldeveloped data collection method, the researcher needs to consider the rationale and logistics of the data collected and a plan for data collection (Punch 2009:160). We set out parameters for each of the questions stated in the study. Parameters entail the choices of data to be collected, whom to collect it from and how frequently. It is essential to select the instrument most appropriate to the study in order to assimilate the necessary information. The qualitative approach relies on the text and image of evaluation and has 'unique steps in data analysis, and draws on diverse strategies' (Creswell 2009:173).

\section{Semi-structured focus group interviews}

A set of questions was carefully compiled and submitted to the respondent (interviewee) in the research project (De Vos 2001:152-153). The researcher arranged for special appointments to conduct relevant interviews, so that the interviewees could participate in semi-structured focus group interviews at schools $\mathrm{A}$ and $\mathrm{B}$ with the different groups of teachers, learners and parents.

Open-ended questions were prepared in advance and an interview schedule was developed to guide the researcher during the interviews, and participants were assisted and encouraged to share their experiences and views regarding the teaching materials and training of teachers regarding the programme (Maree 2010:294). Bless et al. (2013:200) claim that focus groups are used more commonly in qualitative research. The researcher draws up a list of questions to stimulate responses. The participants may discuss the issues among each other. A careful debate among the participants can spark off new knowledge. This method may facilitate the respondents to learn from one another. The facilitators have to use their skills to ensure that the discussion is balanced and that dominant participants allow all to participate.

A small focus group should have 6-10 participants, but we involved 24 participants to ensure rich data. If a heterogeneous group is used, the facilitator must pay attention to power dynamics and ensure that silent people also express their views. The facilitator must not take sides and should take care of the learners in a neutral manner (Bless et al. 2013:214). There is a huge push towards the interactive constructivist approach; however, when implementing instructional technologies, 
there are many challenges with regard to teacher support because of a number of factors such as old-school teachers who are reluctant to use technology because of a fear of the unknown. There are many supporters of this, and they provide a convincing argument. One of the first and most vocal ideas to promote this type of meaningful learning is the use of computers to provide a powerful tool for learning (Papert 1994:35).

\section{Data analysis}

The idea was to conduct a qualitative study to explore and understand the nature of the phenomenon in question (Merriam 1998:80). The qualitative study was conducted in the English class, focusing specifically on reading by using tablets containing audiobooks. In qualitative research, the researchers are key instruments as they are the ones who personally go and collect the information via means of 'examining documents, observing behaviour or interviewing participants' (Creswell 2009:175). The researchers conducted interviews with the participants and coded the responses. Coding can be described as marking the segments of the data using descriptive words (Niewenhuis 2013:99). Descriptive codes were used because they facilitated the interpretation and included a theme that could be linked with the codes. The researchers also used interpretive codes, because they relate to reasons, explanations and motives. Wahyuni (2012:70) is of the opinion that an interpretivist research paradigm can be linked with socially constructed, subjective interpretations of questions. It was feasible to use simple predetermined questions to group the possible topics nested within the questions asked. Themes were then identified as proposed by Creswell (2005:243). The themes centred on the use of the tablets in class referring to practical aspects, challenges using tablets and reading development, learning about phonology (sounds). Boeije (2002:396) focuses attention on the value of comparing responses extracted from the interviewees. The responses were, therefore, compared to achieve an improved understanding of the phenomenon of using tablets to teach reading. Boeije (2002:398) suggests that it is crucial to distinguish between the information gathered from different groups and to establish which themes emerged when studying the data of the different groups. These variations in perceptions are revealed in the next discussion.

\section{Participants}

The participants were all teachers, learners and parents from selected Primary schools in Gauteng in the Atteridgeville environment. The details of the participants are provided in Table 1.

\section{Findings (results)}

Figure 2 shows the classroom situation with the researcher involved in her investigation, busy engaging with the learners using tablets.

\section{Themes}

\section{Practical use of tablets and reading development}

Teachers from School B were advantaged as they had sponsors donating tablets for the entire school. The sponsor serviced the tablets to support the school. Even upgrades were performed to keep up with the latest downloads to enhance the speed and functional operation of the tablets. This school was privileged and the learners' reading abilities developed well because of the use of technology.

TABLE 1: Demographic information of the study participants.

\begin{tabular}{|c|c|c|c|c|c|}
\hline Participant & Gender & Age (year) & Academic background & $\begin{array}{l}\text { Teaching and/or work experience } \\
\text { (teachers and parents) and } \\
\text { learner levels (learners) }\end{array}$ & Language \\
\hline \multicolumn{6}{|c|}{ Teachers: School A } \\
\hline $\operatorname{Tm} 1$ & Male & 34 & B.Tech Education Management & 13 years $(\mathrm{HOD})$ & Tswana \\
\hline Tf2 & Female & 48 & Junior Primary Teachers Diploma & 18 years & Sepedi \\
\hline $\operatorname{Tm} 3$ & Female & 44 & B.Tech Education Management & 15 years & Sepedi \\
\hline \multicolumn{6}{|c|}{ Teachers: School B } \\
\hline Tf4 & Female & 27 & B.Ed Honours in Psychology & 5 years & Xhosa \\
\hline Tf5 & Female & 38 & B.Tech Education Management & 10 years (HOD) & Zulu \\
\hline Tf6 & Female & 41 & Advanced Certificate in Education & 14 years & Zulu \\
\hline \multicolumn{6}{|c|}{ Learners: School A } \\
\hline $\operatorname{Lm} 1-3$ & Male & $7-15$ & Grade 5 & - & Sepedi \\
\hline Lf 4-6 & Female & $7-10$ & Grade 5 & - & Sepedi \\
\hline \multicolumn{6}{|c|}{ Learners: School B } \\
\hline $\operatorname{Lm} 7-9$ & Male & $7-15$ & Grade 5 & - & Zulu and Xhosa \\
\hline Lf $10-12$ & Females & $7-10$ & Grade 5 & - & Zulu and Xhosa \\
\hline \multicolumn{6}{|c|}{ Parents: School A } \\
\hline Pf1 & Female & 27 & Grade 12 & 1 year & Sepedi \\
\hline Pf2 & Female & 46 & Diploma in Human Resource Management & 12 years & Sepedi \\
\hline Pf3 & Female & 30 & TVET: Level 4 Public Relations & 7 years & Tswana \\
\hline \multicolumn{6}{|c|}{ Parents: School B } \\
\hline Pm4 & Male & 43 & Grade 12 & 18 years & Sepedi \\
\hline Pf5 & Female & 37 & Grade 12 and Computer literacy & 9 years & Xhosa \\
\hline Pf6 & Female & 32 & Grade 12 & 14 years & Zulu \\
\hline
\end{tabular}




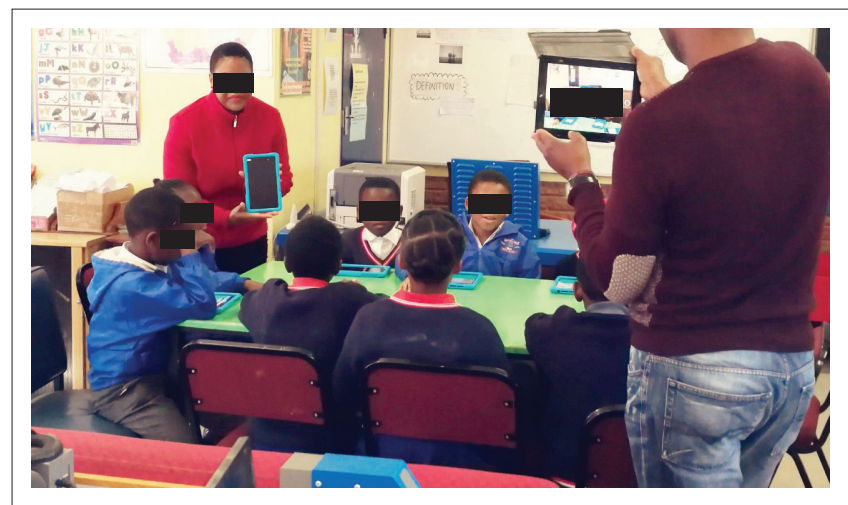

Source: Photo provided by a teacher, Miss Mukwebo, who assisted

FIGURE 2: Tablets implemented to read.

Teachers reported that they made use of technology and prepared the audiobooks before the lessons by selecting appropriate reading material to use for reading aloud sessions when engaging with tablets. They prepared the tablets which came with stories uploaded for the use of Grade 5 learners.

Teachers prepared the tablets containing audiobooks and ensured that they were charged and ready to be used during the reading period. The group leaders collected the tablets and distributed them to fellow group members. Learners listened to the rules for using the tablets in class. The rules were initiated to protect the equipment. The stories listened to on the tablets were I wish I could fly by Elaine Macdonald (2013) and audio recorded by Cathy McCabe specifically for the Intermediate Phase. The questions that were designed to go along with the stories were provided in writing to make the most of the reading lesson. Listening with comprehension was meaningful. The listening activity was also substituted by combining it with writing down the answers to the questions.

\section{Teachers said:}

'Using technology is really a blessing as if classes are interesting, you have fewer discipline problems. I am very positive about using technology as I am a young but enthusiastic teacher. I do not mind the extra preparation to remind the learners about the rules and all the essential conditions of using the tablets.' (Tf4, School B)

'We use our tablets very fruitfully and I can hardly imagine my English classes without them. Once you have grown accustomed to the use of the tablets, you cannot do without them. We do not use smartphones so much for reading as the tablets are very handy and because each learner can use them, it is very convenient. Even though the tablets can also record, it is faster detected by the teacher if the learner is not using it for the purpose of listening to the recordings. The sound is done by connecting the tablets to one speaker which is then operated by the teacher. We do not use earphones as well to deal with the sound. We have detected an increasing willingness to participate as learners feel engaged and they learn the correct pronunciation.' (Tf6, School B)

The findings on teachers' responses prove that the use of tablets as audiobooks in the Second Language Acquisition (SLA) classrooms can improve reading development. All learners showed progress; some rapidly and some steadily. They gradually developed recognition of phonics and the ability to answer questions, because they read aloud and saw the words at the same time. Assessment of their oral marks after having used tablets for six months showed an improvement in pronunciation and reading speed. School A used smartphones to overcome the lack of tablets and the smartphones were just handled by the teachers. When comparing the teaching of school A with the success achieved in school B, it was evident that the use of tablets was more effective.

\section{Learners}

The learners were keen on cooperating and realised the privilege of using the tablets. It was encouraging to hear that the tablets were handled with care in School B. Nobody damaged them on purpose as the teacher explained the rules before using them. The learners also recited the rules along with the teacher to understand the consequences, should they not listen and obey. It should be noted that School A did not have tablets available and the teachers introduced listening to stories via cell phones. The responses from learners in School B revealed that the use of tablets was more efficient than the use of smartphones as incorporated in School A, where there was a mere listening to stories without holding the cell phones, as the teachers just connected speakers to her cell phone. The learners could handle the tablets in School B themselves, had better visual stimulation and felt more involved with the technology in their hands. They were also very much aware of the rules of using technology.

\section{One learner said:}

'Reading lessons using tablets is really a great opportunity to learn. Using the tablets is easy and we focus very well when interested in listening to our audiobooks. I learn new words and I become more fluent when reading after having listened to the stories from the tablets.' (Lf4, School A)

Another learner was of the opinion that:

'Using a tablet is much different from using text books, as the sound is very fascinating and we can hear the correct sounds. We also follow how the words are spelled and it also helps since the tablets provide pictures as well. My vocabulary has already increased since we started using our tablets at school. I remember when I was reading a story during a reading week in the school hall when participating in assembly. I felt as confident as I could experience the benefit of my improved pronunciation. We participated in spelling bee competitions and I felt that I could spell better because of the use of the tablets in class.' (Lm7, School B)

One of the learners who knows how to read in a group taught the weaker learners to follow her, and then they re-listened to the audiobook. The learners were very much engaged in the reading and listening skills, and they also practised their speaking skills when reading aloud with and without the audiobooks on the tablets. 


\section{Reading aloud: Learning about sounds}

Reading aloud helped them to pronounce words correctly and it boosted the learners' self-confidence so that they could read fluently. Learners with visibility and auditory barriers can benefit when using audiobooks on tablets, because they can use their listening ability to listen to the story rather than looking at it. Those who have auditory problems can also benefit because they look at how words are spelled and can be guided by the pictures in the storybook. The challenge is proper training on how to effectively implement audiobooks in the classroom using tablets. The Department of Basic Education should seriously reconsider the use of audiobooks in the classroom as a strategy to enhance reading development and to bring back the love of reading to the technologicallyorientated generation of learners.

The findings of the learner responses reveal that learners are technologically orientated. However, some of them did not know that they could use smartphones, tablets, iPads and computers to listen to audiobooks. Learners are far more interested in listening to audiobooks than in reading from the book. They wanted to use tablets in other learning areas too. From the comparison of the responses of the learners and teachers, it was evident that both the groups were positive about using tablets in both schools, even though School A did not have tablets. Teachers had to put in the effort to prepare everything before the lessons, but the learners participated enthusiastically and adhered to the rules.

\section{Parents}

From the comparison of the responses of the parents and the teachers and learners, it was clear that even though parents were aware of technology, they did not have enough knowledge about what was available on the tablets apart from games, to contribute to improved reading skills. Some parents think that listening to an audiobook on a tablet does not constitute real reading and, perhaps, could even be considered cheating; this perception is only true if the reading process is conservatively defined as decoding the words in a book. However, many literacy skills and strategies used by audiobook readers are comparable to those used by text readers. Wolfson (2008:107) argues that the 'only difference is that we have substituted the visual understanding of written words with the auditory understanding of written words'. Listening allows learners to enjoy a good book while they are multitasking, for example, while mowing the lawn, practising sports, cleaning their rooms or relaxing at home. Parents; however, identified the use of tablets at home as an opportunity to enrich family time. The theme of family time thus featured with parents, whereas teachers and learners were more focused on reading strategies and academic benefits.

\section{One parent said:}

'I think listening to stories from tablets together as a family offers opportunities for shared literary experiences and a springboard for conversation about the story. As parents we will be giving our children support and motivation to read independently and it will boost their self-confidence. Due to funds of buying data
I suggest that the Department of Education can buy tablets or any stakeholder to sponsor schools with tables that have stories that they are using in class.' (Pf5, School B)

\section{Attitudes and motivation}

The attitudes towards the use of technology have both positive and negative attributes. Learning a second language using technology comprises both a teacher's and a learner's involvement. The role of the teacher is to offer control purposes, while the learner's control provides the opportunity to obtain the lessons that have been recorded. Learners are also required to listen to the pronunciation. Research shows that the success of technology used in the educational settings largely depends on teachers' attitudes towards technology use (Albirini 2006:373).

\section{A teacher said:}

'The technology in class gives the learners a sense of independence and the joys of being in school every day. The learners become critical thinkers and they even try to construct their own sentences when working in groups.' (Tf2, School A)

Another teacher said:

'They participate in recapturing the essence and the delights of hearing stories beautifully told by extraordinarily talented storytellers. Decoding is important when teaching learners to read but, understanding the message, thinking critically about the content, using imagination, and making connections are at the heart of what it means to be a motivated reader.' (Tm3, School A)

It is clear that the teacher is more focused on the educational function of the tablet, whereas the learners focus more on the enjoyment thereof. Audiobooks motivate learners, model sound of interpretive reading and introduce learners to books above their reading level. This could also be reflected in the reading style and tone, and whether there are certain tones that convey the read-aloud function more efficiently.

Some parents think that listening to an audiobook does not constitute real reading and, perhaps, could even be considered cheating; this perception is only true if the reading process is conservatively defined as decoding the words in a book. However, many literacy skills and strategies used by tablet (audiobook) readers are comparable to those used by text readers. Wolfson (2008:107) argues that the 'only difference is that we have substituted the visual understanding of written words with the auditory understanding of written words'.

\section{One parent said:}

'I think listening to stories from smartphones or tablets together as a family offers opportunities for shared literary experiences and a springboard for conversation about the story.' (Pf5, School B)

\section{Vocabulary}

Learners learnt new words and became more fluent when reading after having listened to the stories from the tablets. Some of the struggling learners improved especially in School 
B where they had used tablets for the past year as a resource during reading lessons. Struggling learners can now read alone by following the story lines at their own pace. The learners can even compete in reading competitions that are held at school as well as district level.

The parents' responses reveal that they used their tablets to text messages and communicate most of the time. They were pleasantly surprised by the use of the tablets as audiobooks in school and were grateful that it could be used so efficiently. Being informed, they supported the use of tablets and audiobooks as part of their children's reading enhancement.

\section{Struggling learners}

Learners with learning disabilities who listen to audiobooks demonstrate increased literacy skills and reading ability. The language of teaching and learning involves the mother tongue (African languages) which makes it difficult for some learners to understand. Those learners who struggle with reading and writing are motivated by technology, because they are more literate in new literacies and employ scaffolded, traditional literacy (Sylverster \& Greenidge 2009:294).

Struggling learners' comfort level using technology exceeds that of their teachers and parents, and consequently, they confidently explore new devices or other technological tools. Although learners are exploring technology at a rapid rate, teachers and parents often do not recognise the importance of the skills learners develop through independent use of tablets. The successful utilisation of audiobooks in the classroom depends mainly on the teacher's enthusiastic attitude towards technological tools.

One teacher said:

'I see struggling learners pay attention and improve when listening to audiobooks. They gradually develop recognition of phonics and the ability to answer questions because they read aloud and see the words at the same time.' (Tf2, School A)

\section{Challenges}

Perceptions about the value of networking or the use of Internet run deep - especially as it applies to teaching children. There are numerous ways to measure the value of technology in private schools where they use technology as part of their curriculum. Parents reported that technology was in many instances a caretaker at home when they did not have time to spend with their children because of other duties. Access to Internet is somehow a challenge as many respondents reported that they either did not have data or were reluctant to pay for the information at the Internet café.

\section{A participant said:}

'Even though the school has Internet, not all the learners benefit, because they have to do the assignments at home and if you don't stay near the school you don't benefit.' (Pf2, School A)

It became apparent that parents recognised the value of using smartphones, but for many children, Internet access was still a problem at home. Without Wi-Fi, data must be purchased. Parents have also become more informed about healthy social communication and reported that spending too much time on cell phones interferes with family communication.

\section{Recommendations}

The following recommendations are made:

- Audiobooks using tablets can be used in classrooms to improve the learners' level of reading, especially those who are struggling to read.

- Even though teachers are aware of the use of tablets, they still need more training to equip them to learn more about technology application. Their TPACK should be improved in order to know how to share content using technology.

- Parents should be informed about the use of tablets to improve their children's reading and learning and they should be assisted to access appropriate reading books to help their children online.

- Parents should also realise that technology has become an integral part of learners' reading development and their daily lives. Tablets are a need for a modern child and parents should avail themselves to provide their children with the necessary technology to support their education.

- The Department of Basic Education should work handin-hand with schools to ensure that all staff know how to use audiobooks as part of their curriculum.

- The Department of Basic Education should assist schools to obtain funding for technological equipment such as tablets, Internet connections and iPads. The learners should be motivated in using their own smartphones as part of their reading development by downloading free audiobooks.

- The schools should have more reading competitions to encourage interest in reading ability among the learners.

- Parents should be able to download audiobooks for their children and read for them at home.

\section{Conclusion}

The study revealed the benefits of using tablets to teach. The implications of the aforementioned findings are that technological content knowledge should be stimulated in school and in the home environment, because owning a tablet is not enough. Knowledge regarding how to use technology is still a problem. Tablets must be used in a manner that can support learner's development. Much research still needs to be conducted on the use of technology in the educational environment, because not all schools have access to the use of tablets. Future research could focus on the availability and funds provisioning for equipping schools with tablets. Modern learners require adaptation of the old-fashioned focus on reading books in the form of hard copies only. Learners are so technologically orientated that teaching reading is hardly possible without the use of technology. Involving tablets to teach audiobooks provides learners with the valuable and enjoyable experience of using their own imagination to visualise the stories narrated. Technology enhances reading anywhere, because technology equips learners with immediate connectivity in order to read and enjoy. 


\section{Acknowledgements Competing interests}

The authors declare that they have no financial or personal relationships that may have inappropriately influenced them in writing this article.

\section{Authors' contributions}

C.G.A.S. and E.M. conceptualised the article, wrote the first draft and did the literature review. E.M. did the data analysis, M.B. edited the article and assisted with the methodology. M.M. contributed by identifying the theory and assisted with the structure of the article. All authors read and approved the final version of the manuscript.

\section{References}

Albirini, A.A., 2006, 'Teacher's attitudes toward information and communication technologies: The case of Syrian EFL teachers', Journal of Computers and Education 47, 373-398. https://doi.org/10.1016/j.compedu.2004.10.013

Aparicio, M., Bacao, F. \& Oliveira, T., 2016, 'An e-Learning theoretical framework', Educational Technology \& Society 19(1), 292-307.

Boeije, H., 2002, 'A purposeful approach to the constant comparative method in the analysis of qualitative interviews', Quality and Quantity 36, 391-409. https://doi. org/10.1023/A:1020909529486

Bless, C., Higson-Smith, C. \& Sithole, L., 2013, Fundamentals of social research methods. An African perspective, Juta, Cape Town.

Carbo, M., 1996, 'Reading style: High gains for bottom third', Educational Leadership 53(5), 8-15.

Choate, J., 2004, Successful inclusive teaching, Pearson, Boston, MA

Creswell, W.J., 2005, Educational research: Planning, conducting and evaluating quantitative and qualitative research, 2 nd ed., Sage, London.

Creswell, J.W., 2009, Research design: Qualitative quantitative and mixed method approaches, Sage, London.

Cuban, L., 2001, Oversold and underused: Computers in the classroom, Harvard University Press, Cambridge, MA.

Dawson, C. \& Rakes, G.C., 2003, 'The influence of principals' technology training on the integration of technology into schools', Journal of Research on Technology in Education 36, 29-49. https://doi.org/10.1080/15391523.2003.10782401

De Vos, A.S., 2001, Research at grass roots: A primer for the caring profession, Van Schaik, Pretoria.

Eberwein, D., 2013, Curriculum trends in education, viewed 19 February 2014, from http://www.examiner.com/article/curriculum-trends-education

Eickelmann, B., 2011, 'Supportive and hindering factors to a sustainable implementation of ICT in schools', Journal for Education Online 3(1), 75-103.

Engelbrecht, A., Nel, M. \& Hugo, A., 2012, 'Strategies for supporting language', in A. Engelbrecht, H. Swanepoel, M. Nel \& A. Hugo (eds.), Embracing diversity through multilevel teaching for foundation, intermediate and senior phase, Juta, Cape Town.

Fuller, H.L., 2000, 'First teach their teachers: Technology support and computer use in academic subjects', Journal of Research on Computing in Education 32(4), 511-535. https://doi.org/10.1080/08886504.2000.10782295

Gauteng Department of Education, 2010, Gauteng Primary Literacy Strategy, 2010 2014, Pretoria.

Glazer, E., Hannfin, M.J. \& Song, L., 2005, 'Promoting technology integration through collaborative apprenticeship', Educational Technology Research and Development 53(4), 57-67. https://doi.org/10.1007/BF02504685
Iding, M., Crosby, M.E. \& Speitel, T., 2002, 'Teachers and technology: Beliefs and practices', International Journal of Instructional Media 29(2), 153-171.

Klein, K. \& Myers, D.M., 1999, 'A set of principles for conducting and evaluating interpretive field studies in information systems', Management Information Systems Quarterly 23(1), 67-93. https://doi.org/10.2307/249410

Koehler, M.J. \& Mishra, P., 2009, 'What is technological pedagogical content knowledge?', Contemporary Issues in Technology and Teacher Education (CITE Journal) 9(1), 60-70.

Larson, L.C., 2015, 'E-books and audiobooks: Extending the digital reading experience', The Reading Teacher 69(2), 69-177. https://doi.org/10.1002/trtr.1371 @ 2015 International Literacy Association

Leipzig, D.H., 2001, What is reading. Reading rockets, viewed 18 March 2017, from http://www.readingrockets.org/article/what-reading

Macdonald, E., 2013, I wish I could fly, viewed 15 July 2017, from file:///storage/ emulated/0/english/level3/intermediate/i_wish_i_could_fly/page00.html.

Maree, K. (ed.), 2010, First steps in research, Van Schaik, Pretoria.

McMillan, J.H. \& Schumacher, S., 2010, Research in education: Evidence-based inquiry, Harper Collins College, New York.

Merriam, S.B., 1998, Qualitative research and case study applications in education Jossey-Bass, San Francisco, CA.

Middleton, B.M. \& Murray, R.K., 1999, 'The impact of instructional technology on student academic achievement in reading and mathematics', International Journal of Instructional Media 26(1), 109-116.

Moersch, C., 1999, 'Assessing current technology use in the classroom: A key to efficient staff development and technology planning', Learning and Leading with Technology 26(8), 40-49.

Nehme, Z, 2000, 'The social arena of the online synchronous environment', Turkish Online Journal of Distance Education 9(2), 238-249.

Nel, N. \& Nel, M., 2012, 'English language', in N. Nel, M. Nel \& A. Hugo (eds.), Learner support in a diverse classroom, Van Schaik, Hatfield.

Niewenhuis, J., 2013, 'Qualitative research designs and data gathering techniques', in K. Maree (ed.), First steps in research, Van Schaik Publishers, Hatfield.

Papert, S., 1994, The children's machine: Rethinking school in the age of the computer, Basic Books, New York.

Pogue, D., 2010, 'The Apple iPad: First impression', New York Times, 27 January, 2010 viewed 14 November 2011, from https://pogue.blogs.nytimes.com/2010/01/27/ the-apple-ipad-first-impressions/

Punch, K.F., 2009, Introduction to research methods in education, Sage, London.

Robles de Meléndez, W. \& Beck, V., 2007, Teaching young children in multicultural classrooms. Issues concepts and strategies, Thomson Delmar learning, New York.

Royer, R., 2002, 'Supporting integration through action research', The Clearing House 75(5), 233-237. https://doi.org/10.1080/00098650209603946

Sara, A., 2009, The Literacy Toolkit: Improving students' speaking, listening, reading and writing skills, Crown House, New York.

Shulman, L.S., 1986, 'Those who understand: Knowledge growth in teaching', Educational Research 15(2), 4-14. https://doi.org/10.3102/0013189X015002004

Siemens, G., 2005, Connectivism: Learning as network creation, viewed 12 August 2017, from http://www.elearnspace.org/Articles/networks.html

Sylverster, R. \& Greenidge, W., 2009, 'Digital storytelling: Extending the potential for struggling writers', The Reading Teacher 63(4), 284-295. https://doi.org/10.1598/ RT.63.4.3

Thyer, B.A., 1993, 'Single-system research designs', in R.M. Grinnell (ed.), Social work research and evaluation, Peacock, Itasca, IL.

Wahyuni, D., 2012, 'The research design maze: Understanding paradigms, cases, methods and methodologies', JAMAR 10(1), 69-80.

Welman, C., Kruger, F. \& Mitchell, B., 2005, Research methodology, Oxford, Cape Town.

Wolfson, G., 2008, 'Using audiobooks to meet the needs of adolescent readers', American Secondary Education 36(2), 105-114.

Zarfass, J., 2001, 'Sustaining a curriculum innovation: A case of make it happen!', in J. Woodwards \& L. Cuban (eds.), Technology, curriculum and professional development: Adapting schools to meet the needs of students with disabilities, pp. 87-114, Corwin, CA. 